RESEARCHARTICLE

\title{
Understanding the Moral Values of Young People and the Key Influences on their Character Development
}

\author{
Beng Huat See* \\ School of Education, Durham University, Durham, UK
}

\begin{abstract}
The aim of the paper is to explore young people's perceptions of moral values and the kind of influences that shape their behaviour. The study is based on the perceptions of 1,997 children in England at the point of transition from primary to secondary school. Data was collected from interviews, questionnaire surveys, and documentary analysis. The findings suggest that young people have a good understanding of moral values. They value trust and honesty above all values. Tolerance and courtesy were less valued. Young people also demonstrate a high level of moral awareness and an understanding of what makes a "good" person. Primary pupils were more likely than secondary pupils to trust their teachers and see them as important moral agents. This is important for children who come from homes where there is a lack of positive role models. If schools and teachers are to play a role in the character development of young people, efforts have to be made to build that trust and respect. And teachers themselves could help by modelling the kind of behaviour they want to see in the young people. Future research could examine how teachers' behaviour can influence young people's concept of morality.
\end{abstract}

\section{Keywords}

Open Access

Citation: See, BH. Understanding the Moral Values of Young People and the Key Influences on their Character Development. Interdisciplinary Education and Psychology. 2018; 2(2):1.

Received: April 19, 2018 Accepted: August 06, 2018 Published: August 26, 2018

Copyright: (๑) 2018 See BH. This is an open access article distributed under the terms of the Creative Commons Attribution License, which permits unrestricted use, distribution, and reproduction in any medium, provided the original author and source are credited.

\section{Corresponding author:} BengHuat See, School of Education, Durham University, Leazes Road, Durham, UK

E-mail: b.h.see@durham.ac.uk
Character, values, transition phase, pupils' perspectives, role of teachers

\section{Introduction}

Over the last two decades the behaviour of our youth as an educational issue has become part of the political agenda in England. When the new Labour government came into office the first White Paper on education, Excellence in Schools (DfEE ${ }^{1}, 1997$, p. 10), stated that schools and families should take responsibility for the character development of children. Eighty-five percent of those who responded to the Green Paper Schools: Building on Success (DfEE, 2001) supported the provision of 'education with character' (DfES, 2001). When riots broke out across the England in 2011, David Cameron, the then Prime Minister, attributed the unrest to the 'twisted moral code' of the young people (Cabinet Office, 2011), and put the responsibility on parents and schools to bring about changes in young people's understanding of morality (Cabinet Office, 2011). The independent report Riots, Communities and Victims Panel, appointed in the aftermath of the riot recommended further study of character education in British schools.

Despite such strong rhetoric, government initiatives to enhance character education remained patchy and marginal (Arthur et al. 2010). A survey of 1,000 teacher trainees suggests that teacher trainees were not adequately equipped with the skills for moral development (Revell \& Arthur, 2007). While character education is seen as part of citizenship education, it is not part of the curriculum in teacher education. As in the UK, character education in the US had also been described as unsystematic and uncontrolled (Berkowitz,

${ }^{1}$ DfEE Department for Education and Employment, now known as the Department for Education (DfE) 
2012), and there was also an overwhelming support for character education (Matera, 2001).

In December 2014, the coalition government announced in a $£ 3.5$ million education grant to support projects in character education in schools. An additional $£ 1$ million was made available to the Education Endowment Foundation to test the most effective ways of developing character in school. A number of trials have been funded to test various programmes aimed at developing the wider outcomes of young people. Examples of these include the Youth United Youth Social Action programme (Gorard \& Siddiqui, 2017) and Changing Mindsets (Rienzo et al. 2015).

The recent spike in knife crimes in the streets of major cities in the UK and the increasing incidence of cyber bulling have again caused the government to look to schools for a solution to youth behaviour. In 2017, a report was commissioned by the Department of Education to look at how schools can foster positive character traits in young people (DfE, 2017). The report found that despite the millions of pounds spent on projects to teach character, over half of the teachers surveyed said they did not have the time to develop character traits among pupils because of the pressure of exams (DfE, 2017).

There has been much research conducted, mostly in the US, to develop and enhance character to address problem behaviour among young people (e.g. Flay et al. 2012; WebsterStratton et al. 2008; Battistich et al. 2004; Battistich, 1997; Dietsch, Bayha \& Zheng, 2005; Berkowitz \& Bier, 2004). Few studies have actually sought to understand the kind of values young people hold, or their perception of what a "good" person is and who or what influenced their values.

It is widely acknowledged that at an early age a child's character and the kind of values they hold are largely shaped by a combination of personal and social interaction with parents, carers, siblings and other relatives (Berkowitz,1997; Lexmond \& Reeves, 2009) and that parents have an important influence. Others, however, have argued that a child's moral character can be altered or influenced by their interactions with others outside the family (Borba, 2002; Berkowitz,1997). The influence of peers and school, for example, has also been widely recognised (Borba, 2002). As Durkheim stated:

Contrary to the all too popular notion that moral education falls chiefly within the jurisdiction of the family, I judge that the task of the school in the moral development of the child can and should be of the greatest importance. (Emile Durkheim, 1961, pp.18-19).

In this study we use the term character loosely to refer to a set of behaviour, beliefs and attitudes that is shaped by the kind of values that one holds. These values are either taught or picked up through interactions with others (Campbell \& Bond, 1982). Moral character, as conceptualised by Cohen and Morse (2014), is understood to be an individual's disposition to act, behave, think and feel in ethically and socially acceptable ways. In this study, moral values are conceived as values that are generally associated with ethical behaviour as defined by the Joseph Institute of Ethics (https://web.engr.uky.edu/ jrchee0/CE\%20401/Josephson\%20 EDM/Making_Ethical_Decisions.pdf). These include honesty, loyalty, justice, tolerance, trust, self-control, kindness, generosity, respect and justice or fairness. A good person is therefore taken to mean one who demonstrates these character traits.

The focus of the study is on the transition phase when children move from primary to secondary school. This period, also known as the pre-teen years, is considered pivotal in the character development of young people (Zeedyk et al, 2003). Faced with new circles of pupils and new teachers who may hold values that are significantly different from those they experienced in the primary setting and may be at variance with those that they may possess, can be a source of confusion and frustration (Graham \& Hill, 2003, Tobbell, 2003, Thompson, 2004; Weller, 2007). Literature on transition in the last two decades suggest that many behavioural problems associated with early teens such as truancy, non-compliance and inappropriate behaviour can often be attributed to these changes (Hargreaves et al. 1996; Eyers et al. 1992; Measor \& Woods, 1984). There is also evidence that the negative effects of transition can have an impact upon sustaining and developing character (Harter, 1985).

In England, the Department for Children, Schools and Families (DCSF), now known as the DfE (Department for Education), commissioned research into what makes a successful transition (Evangelou et al. 2008). It is because of the importance of this period in the development of a child's character, and the lack of coherence in the provision of character education in England that we have chosen to focus on young people's values during transition. 
It is hoped that understanding young peoples' perceptions of values and the important influences that shape their moral character will provide clearer strategies to address problem behaviour associated with the transition period.

It is perhaps worth mentioning that the purpose of the paper is not to suggest or prescribe a moral code. Here we are trying to capture young people's perceptions of what they understood to be a good person, what values are important to them and whether these are at variance with common understanding of good behaviour. Moral values are a subjective concept and a person's understanding of what is moral or not may be different to another person's. Therefore, children's understanding of what makes a good person and the values they hold important may not align with those of the adults'. One culture's core values may be different to another's. Understanding their perceptions and the factors influencing their behaviour is a first step towards helping young people in their character development. It is not the purpose of this paper to go into a philosophical debate into what are "good" or "right" moral values. This would be a different paper altogether. In any case, the kind of values that emerged from the interviews and questionnaire responses are consonant with the kind of values that Aristotle extolled, and widely recognised as good moral values.

\section{Method}

The aim of this paper is to understand the moral values of young people (children aged 10 to 12), the qualities they associate with a good person and what they perceive to be the main influences in the formation of their own character.

This paper will address the following questions:

1. What are pupils' perceptions of moral values?

a) What qualities do they associate with good people?

b) Do they see themselves as having qualities associated with good people?

2. What do pupils consider as important factors in their character development?

3. To what extent do schools/teachers influence pupils' values?

The sample was taken from eleven state schools ( 5 primary and 6 secondary) in the Southeast of England. These schools included grammar and non-selective schools located in an area considered to be socioeconomically below the national average. Pupils in the study included 10 and 11 years olds in their final year of primary education, known as Year 6 (Y6) and 11 and 12 years olds in their first year of secondary education, known as Year 7 (Y7).

Data was collected from group interviews with pupils and two questionnaire surveys. This paper reports largely on the findings from the interview data. Responses from the questionnaire survey are used to establish some preliminary information about pupils' values and their perceptions of good people. Documentary analysis of school prospectuses and Ofsted reports are used to substantiate the findings.

\section{Pupil interviews}

The interview schedule (Appendix A) was designed in the light of findings from both literature reviews and an earlier study conducted in Bristol. Pupil interviews were conducted in groups of six in each of the participating primary and secondary schools. In total 11 group interviews involving 106 pupils were conducted across the schools. Parental consent was obtained for those pupils involved in the interviews. Each group interview consisted of 25-35 minutes of highly structured questions from the researcher and discussion by the students, followed by ten minutes of written reflections by pupils. The schedules are predominantly open-ended questions designed to find out pupils' understanding of good character, the kind of values they hold, where they see their particular character traits emanating from, and sources that influence their core selves. A couple of these questions were presented as vignettes of hypothetical values-related situations and pupils were asked how they would respond to such dilemmas. To elicit a working definition of what constitutes good character, pupils were asked to identify one or two people who they perceive as good people and the characteristics that define them as "good".

\section{Questionnaire survey}

Two self-report questionnaires were developed to collect data concerning pupils' perceptions of values, their understanding of a "good" person and what they identify as key 
influences in their character development. These items were created following the development of a conceptual framework of character formation, which were identified from a synthesis of the findings from the focus group discussions, and interviews with teachers. Data on students' demographic characteristics such as sex and religion was also collected in order to explore the influence of these factors on pupils' responses.

The first questionnaire (Appendix B) is about pupils' perceptions of a good person and whether they think they have lived up to the expectations of a good person. It consists of 55 items. The first 7 items collect information on pupils' demographic background. The other 48 items are Likert scale questions with five responses ranging from 1 (strongly agree) to 5 (strongly disagree). Items 1 to 21 is a list of character traits to elicit pupils' perceptions of what they think makes a good person. For example, it is debatable whether attending a place of worship or caring for the environment makes one a good person. It is hoped that answers to these questions would provide an insight into young people's understanding of a moral person. Here we are not trying to prescribe to young people how they should behave, but to understand why they behave the way they do.

Questions 22 to 42 ask students if they think they have these qualities (e.g. "I am kind and caring"; "I am trustworthy"; "I have a religious faith"). Questions 43 to 48 concern the influences on pupils' values and character. A question about pupil's religious faith was included as religion and morality are often believed to be closely related, and may be considered an important factor influencing one's perceptions of what is "good" and "bad".

The aim of the second questionnaire (Appendix $\mathrm{C}$ ) was to find out about the kind of values young people hold important and how the media, schools, teachers and peers have an influence on their character. It consists of 83 items. Examples of questions include: "I am taught how to be a good person by my teachers"; "Teachers ask me my opinion in school"; "TV influences my behaviour"; "My friends influence how I act and behave".

For this paper, only selected items from the two questionnaires and pupil interviews that pertain to the focus of this paper were used. For example, items relating to citizenship are not discussed in this paper. Items 44a-f of Questionnaire 2 provide the answers to Research Question 1 about the kind of values children hold important. Items 18 to 20 assess pupils' understanding of values such as justice (item 18) and honesty (items 19 and 20). To get a sense of young people's moral awareness we asked them about common moral issues they faced in school. These were presented as vignettes in interview items 6 and 7 (Appendix A), which helped to define children's character traits, such as self-control (item 6 of the interview schedule), compassion and empathy (item 7 of the interview schedule).

Items 1-21 of Questionnaire 1 are about pupils' perceptions of a good person (Research Question 1). Items 43 to 48 are relevant to Research Question 2. These questions ask children to identify the key influences in their character development. Answers to Research Question 3 are taken from Questionnaire 2, items 2, 7, 24, 25, 55, 56 and 57 and Questionnaire 1, item 46 and 47.

\section{Administration of questionnaires}

Questionnaire One was administered to 997 pupils, with a 100\% response rate. Table 1 gives a breakdown of the sample by year group and sex. Questionnaire Two was administered to 1,130 pupils in the participating schools, with a response rate of $88.5 \%$. All participants were assured of anonymity and confidentiality. Participants were:

- Informed of the purpose of the research and the questionnaire;

- Asked for their permission to participate through informed consent and parental letter;

- Informed that all information would be treated confidentially and anonymously;

- $\quad$ Advised of rights to withdraw;

- Encouraged to complete the questionnaire in their registration period or lesson. 
Table 1.Sample by year group and sex

\begin{tabular}{|l|c|c|c|c|c|c|}
\hline Year Group & \multicolumn{2}{|c|}{ Male } & \multicolumn{2}{c|}{ Not male } & \multicolumn{2}{c|}{ Total } \\
\hline & Q1 & Q2 & Q1 & Q2 & Q1 & Q2 \\
\hline 6 & $54 \%$ & $55 \%$ & $46 \%$ & $45 \%$ & 148 & 109 \\
\hline 7 & $57 \%$ & $57 \%$ & $43 \%$ & $43 \%$ & 852 & 888 \\
\hline Total & 565 & 568 & 435 & 429 & 1000 & 997 \\
\hline
\end{tabular}

\section{Analysis of interview data}

All interviews were recorded on digital audio equipment and were then transcribed. The interview data was categorised and synthesised according to the following themes:

- Pupils' understanding of what makes a good person

- Pupils' reported influences on their behaviour

A descriptive account of the findings was then produced for each of these themes. The responses from these group interviews helped formulate the questionnaire items and also illuminated findings from the questionnaire survey (Morgan, 1988; Knodel, Havanon \& Pramaulratana, 1984).

\section{Analysis of survey data}

Once the data was collected, a coding sheet was developed and question items were coded and pupils' responses entered into SPSS. Simple descriptive statistics were performed on the data collected using the SPSS statistical package. Responses were compared by year group using the cross tabs process within SPSS. Where appropriate, data from the group interviews was used to illuminate the survey findings. As the sample was not random but involving the whole cohort of $Y 6$ and $Y 7$ pupils in the participating schools, significant testing was not appropriate. For categorical variables like the kind of values pupils hold important, comparisons were made using odds ratios, that is, how likely are primary school pupils to rate those values as important compared to secondary school pupils. The five-point Likert scale was collapsed to form a binary scale (Agree and Not Agree). Strongly Agree and Agree were combined and recoded as Agree, while Strongly Disagree, Disagree and Neither were combined and recoded as Not Agree. According to Grassi et al. (2007), such recoding would not result in any loss of internal structure while maintaining internal consistency and comparable values as the Likert scales.

\section{Findings}

\section{Pupils' perceptions of moral values}

To get a sense of pupils' moral values, we used six items identified by the Joseph Institute of Ethics as those that most people associate with ethical behaviour. Pupils were asked to rate how important these were to them. To these young people values such as Trust and honesty (Table 2) were considered very important, while Courtesy and tolerance were seen as less important (Table 2). In general there was little difference in the views of $Y 6$ and $Y 7$ pupils. However, the younger Y6 pupils were more likely than the older $Y 7$ pupils to report Courtesyas important to them.

Table 2. Values pupils agree was important (\%)

\begin{tabular}{|l|c|c|c|c|c|}
\hline \multirow{2}{*}{ Values } & \multicolumn{2}{|c|}{ Agree } & \multicolumn{2}{c|}{ Not agree } & $\begin{array}{c}\text { Odds } \\
\text { ratios }\end{array}$ \\
\hline & $Y 6$ & $Y 7$ & $Y 6$ & $Y 7$ & \\
\hline Trust & 85 & 89 & 15 & 11 & .79 \\
\hline Honesty & 79 & 85 & 21 & 15 & .70 \\
\hline Loyalty & 77 & 79 & 23 & 21 & .89 \\
\hline Justice & 68 & 72 & 32 & 28 & .81 \\
\hline Courtesy & 67 & 65 & 33 & 35 & 1.1 \\
\hline Tolerance & 58 & 60 & 42 & 40 & .89 \\
\hline
\end{tabular}

$\mathrm{N}(\mathrm{Y} 6)=109 ; \mathrm{N}(\mathrm{Y} 7)=888$

We further asked them in interviews to identify characteristics associated with good people. 
They named 49 different qualities, which were mentioned a total of 190 times across the 11 group interviews. The most frequently mentioned qualities in order of frequency were:

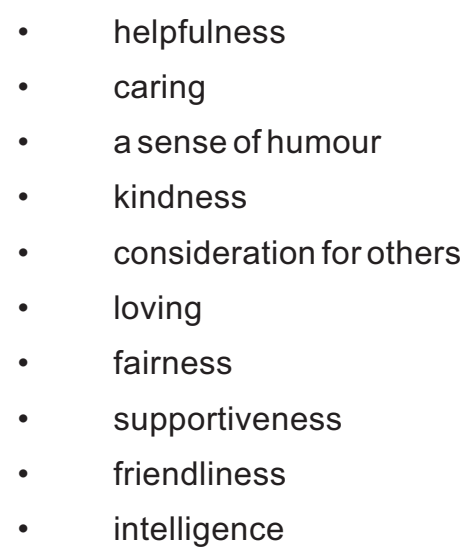

Although pupils generally had a common understanding of what constitutes a good person, there were some differences in the perceptions of primary and secondary pupils. Secondary pupils did not see qualities like having a 'sense of humour', 'being fair' and 'determined' as important in a good person as they did for primary school pupils. On the other hand, qualities like being considerate, friendly and understanding, which were not mentioned by primary pupils featured in the responses among Year 7 students.

Generally, pupils perceived kind people as those who would 'give you time', would be 'helpful', 'put others first' and are'generous'. For example, one pupil said:

Like if they a big packet of sweets, they'd just share them out with people, even people they didn't like.

They will do things without expecting anything in return. If somebody is upset, they will make them happy again.

Pupils also identified a good person as someone who cares and supports them, is patient, kind and helpful. Excerpts from group interviews:

Like Mrs. D, she helps us, she pushes us and the reason she does that is because she cares. She never gives up on us. When we've got football matches, she always supports us. And even when the other team are winning, she still supports us. Also when we're in a lesson and she's gone over something 20 million times, she'll still go over it again to make sure that you've understood it.

Johnnie as well, because he's always helping the little ones. And some people say things and it hurts your feelings, but Johnnie knows what to say and he knows not to hurt your feelings.

Y6 pupils

These responses reflect a sense of moral awareness among young people, and suggest that they were able to identify appropriate qualities associated with good character. The majority of the pupils also believed that they possessed these characteristics. Seventy percent of pupils believed that they were 'responsible', 'friendly', 'helpful' and 'welcoming', while $66 \%$ thought of themselves as 'trustworthy' and 'loyal'. Over half (64\%) saw themselves as 'kind', 'caring' and 'loving'.

To explore the extent to which pupils shared the qualities they had described as being those of a good person, they were presented with a dilemma. Pupils were asked to choose between going to a local shop to buy milk for a retired neighbour, who had asked them for help, or to go and play with their friends. Pupils' responses suggest qualities of empathy and compassion. Almost all the pupils said they would help their elderly neighbour. Comments included: 'a weak older person', 'old people find it hard to move', 'imagine it was our parents'. Some pupils said they would do it out of commitment to their neighbour, others said it was because of the trust that the neighbour had in them. There was no perceptible difference in the range of responses to the scenario between the primary and secondary pupils, although there was a certain level of maturity in some of the answers given by the younger pupils. For example,

It's only 5 minute's of your day and it saves another person from being injured.

We'll just say to our friends we're going to get some milk for someone. And if they say "Ha 
ha! You're not going to do that are you?" and "They're really old". And it's not very kind of them to say that. So I would say, "That's not very kind," and "if you think that you're not my real friend".

When asked about their motivation for doing good deeds, pupils said:

It makes you feel warm inside. (Y6 pupil)

I feel good because it makes [my father] feel good. (Y6 pupil)

Youget to help others. (Y7 pupil)

If you are nice otherpeople will be nice back. (Y7 pupil)

You get a nice feeling that you've helped someone. (Y7 pupil)

To understand pupils' conception of friendship and kindness they were asked how they would react to a hypothetical situation in which their friend's incessant talking kept them from doing their schoolwork. Here again pupils demonstrated a level of maturity with regards to handling the conflicting situation. While they were aware of the importance of getting schoolwork done, they were also careful not to damage their friendship. Here are some responses from the pupils:

If you are unkind, you won't have any friends. (Year 7 pupil)

If they are your true friends, you'd probably act kinder. (Year 7 pupil)

I wouldn't be unkind to them...they are your friends and they are there for you. They are the people who are going to play with you, will look out for you and some people won't do that foryou. (Year6 pupil)

Many also said they would do it with tact and diplomacy.

When pupils were asked if they identified themselves as a good person, the majority believed that they were good, but there was a general acknowledgement that being good was a matter of choice, and that an individual can choose to be good or not.

For the majority of pupils, the term good was seen within the framework of doing good as opposed to being good. They interpreted being good with doing the things that adults wanted them to do, for example doing homework, tidying a bedroom, not talking in class, not running in the corridor. Pupils' comments suggested that they perceived being good all the time as the opposite of fun and that such behaviour would annoy friends, which would put them at risk of being excluded from friendship groups. The following comments exemplify this perception:

Yes, I do want to be a good person, but not all the time, I want to have fun with my friends. (Year 7 pupil)

I don't want a reputation of always being good. (Year 6 pupil) [...] you wouldn't join in. (Year 6 pupil) [...] you want to be popular. (Year6 pupil)

A number of pupils perceived certain personal advantages of being good, for example, achieving academically and having more friends:

I do like being a good person and yes I want to be a good person because if I was bad I wouldn't get good grades in a test. (Year 7 pupil)

\section{[...] if you are unkind you won't have any friends. (Year 7 pupil)}

However, when pupils were asked to consider the qualities they had identified as those belonging to a good person in the negative (e.g. unhelpful, unforgiving, unloving etc.) and to apply them to themselves, they all agreed that they would not like to be that sort of person.

\section{Key influences of children's behaviour}

Kohlberg's theory of moral development suggests that young people's sense of morality is constructed through their interactions with others (Kohlberg, 1976). Research points to several key intrapersonal factors that increase a child's risk for behavior problems (Guerra et al. 1995). These risk factors include poor parental supervision and monitoring (Gorman-Smith et al. 1996), association with aggressive peers (Hawkins et al. 2000) and exposure to community violence (Schwartz \& Proctor, 2000).

Role models are therefore central to moral development. In this study pupils were asked in the survey to consider who and what had helped them to be a good person and the ways in which they had been helped. Family (parents and careers) was reported as having the most influence on their character development (Tables 3 and 4). 
Table 3. Supportive variables that help students understand how to be a good person

\begin{tabular}{|l|c|c|}
\hline \multirow{2}{*}{ The following help me to know how to be } & \multicolumn{2}{|c|}{ Percentage agree (\%) } \\
\cline { 2 - 3 } & Year 6 & Year 7 \\
\hline a) Mother/female carer/guardian & 85 & 89 \\
b) Father/ male carer/guardian & 76 & 79 \\
c) Sisters/brothers & 55 & 53 \\
d) Grandparents & 70 & 74 \\
e) Friends & 60 & 63 \\
f) Teachers & 72 & 50 \\
g) School & 57 & 51 \\
h) People on TV & 33 & 27 \\
i) Going to my place of worship & 27 & 30 \\
j) No one, I know how to be good myself & 32 & 26 \\
\hline
\end{tabular}

$\mathrm{N}(\mathrm{Y} 6)=148 ; \mathrm{N}(\mathrm{Y} 7)=852$

Table 4. Supportive variables that help students to act like a good person

\begin{tabular}{|l|c|c|}
\hline \multirow{2}{*}{$\begin{array}{l}\text { The following help me to act like a good } \\
\text { person }\end{array}$} & \multicolumn{2}{|c|}{ Percentage agree } \\
\cline { 2 - 3 } & & Year 6 \\
a) Mother/female carer/guardian & 82 & 86 \\
b) Father/ male carer/guardian & 75 & 74 \\
c) Sisters/brothers & 49 & 52 \\
d) Grandparents & 68 & 70 \\
e) Friends & 56 & 61 \\
f) Teachers & 66 & 51 \\
g) School & 55 & 51 \\
h) People on TV & 29 & 26 \\
i) Going to my place of worship & 26 & 31 \\
j) No one, I know how to be good myself & 26 & 26 \\
\hline
\end{tabular}

$\mathrm{N}(\mathrm{Y} 6)=148 ; \mathrm{N}(\mathrm{Y} 7)=852$

This is consistent with many earlier studies that suggest a strong influence of parents or parenting styles on character development (Holstein, 1976; Walker \& Taylor, 1991; Speicher, 1994; Borba, 2002). According to Berkowitz and Grych (1998), parenting styles have powerful influences on children's moral reasoning, self-esteem, self-control, compliance, altruism, conscience, empathy and social orientation. Berkowitz (1997) explained that mothers can help develop children's conscience and moral reasoning by providing a warm and mutually positive basis for interaction.

Pupils explained that it was the love and examples that their primary carers set that helped develop their character. For example, one Y6 pupil said 'family are kind and loving', and another suggested that her mother taught her to be good, was 'always there for her' and was a good person. Pupils in one secondary school explained that their mothers had a greater influence on them because 'she builds your confidence', 'she helps with homework' and she shows 'a lot of interest'. One reason for the strong influence of the family is the amount of time pupils spent with them, as some pupils explained:

\section{[...] my parents build my character because I see my parents more than my gran.}

[...] the people who influence me the most are my parents because I see them every day and I spend a lot of time with them.

For secondary school pupils 'friends' came after 'family as the next most influencing factor on their moral development. This concurs with previous research (Layard, 2005; Layard \& Dunn, 2009), which highlights the influence of friends on the wellbeing, achievement and identity of pupils particularly during the transitional phase (Tobbell, 2003; Weller, 2007). In group interviews pupils explained how their peers might influence their behaviour. For example:

If your friends are good people that encourage you to be good then you want to be like 
them to be friends with them. (Year 7 pupil)

\section{[...] if you are hanging around with bad people, it can make you bad. (Year 6 pupil)}

My friends are kind and they set a good example to me. But if they were bad I would be bad(Year6).

Primary school pupils, on the other hand, were more likely than their older peers to rate their teachers as more important than their friends in influencing their behaviour. Responses from some secondary pupils shed insight into why this might be so. They believed that having a single teacher in primary school helped them to build trust in that person. In the secondary school they have more than one teacher and even though they could still trust their teachers they are forced to 'think' more for themselves about moral issues. This explains the change in the relationship with the teachers.

Contrary to common perceptions, TV personalities and religion did not exert much influence on pupil's conception of morality. But interestingly, children also cited the influence of other people around them. For example, one child explained how the people they interacted with can influence their own behaviour:

[...] if you are around with good people you want to be like them so you naturally 'be' more of a good person... if you are around with bad people, then I don't think your instinct would be to be good.

\section{The influence of school and teachers on character development}

The school, as a whole, did not appear to have much of an influence on pupils' character formation. Only half of the pupils reported in the survey that their teachers had helped them to develop their character. However, primary school pupils were more likely than their secondary school counterparts to perceive their teachers as instrumental in their character development (Figure 1). They were also more likely to agree that it was their teachers who helped them to know how to be a good person and how to act like one (Figure 2)

Figure 1. My teacher helps me develop my character

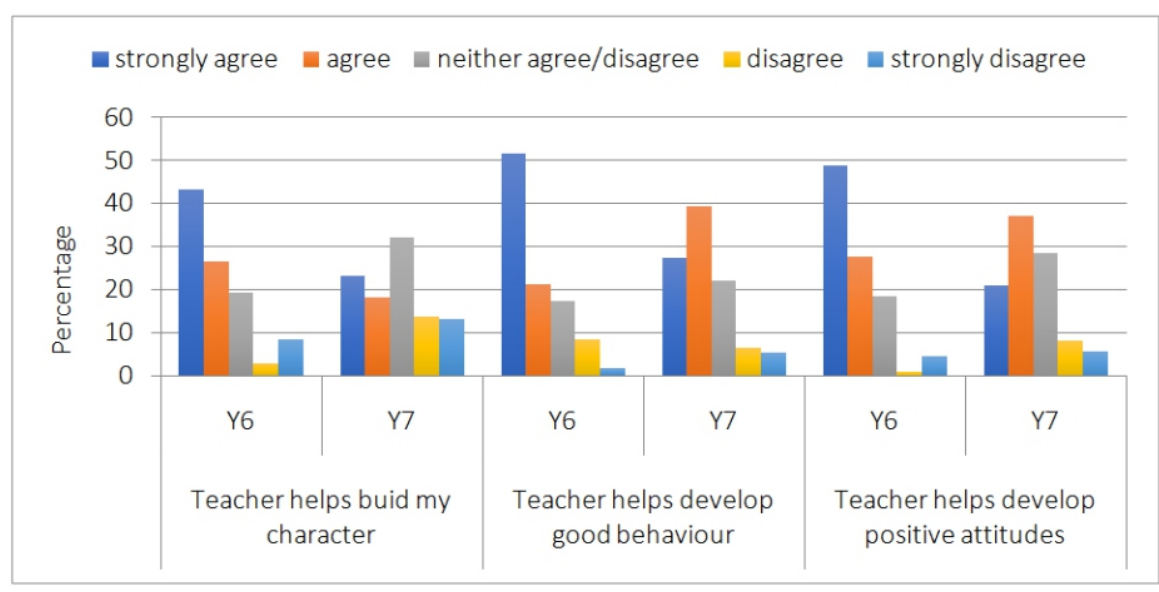

There are many possible reasons for this difference in attitude. Documentary analysis and interviews with teachers suggest that there was a close teacher-pupil relationship in primary schools, but not so in secondary schools. Ofsted report in one school highlighted the good relationships teachers had with their pupils across the school. In another primary school, the head teacher and teaching staff were commended for making themselves easily available for parents to contact, in support of the school's policy of 'close contact and cooperation'. This, however, was not evident in the secondary schools.

Primary school teachers were also more likely than secondary school teachers to see themselves as moral agents. A number underlined the importance of role modelling. This is summarised in the following comments by a primary school teacher: 
Figure 2. Teachers teach me how to make decisions about moral issues or problems in life

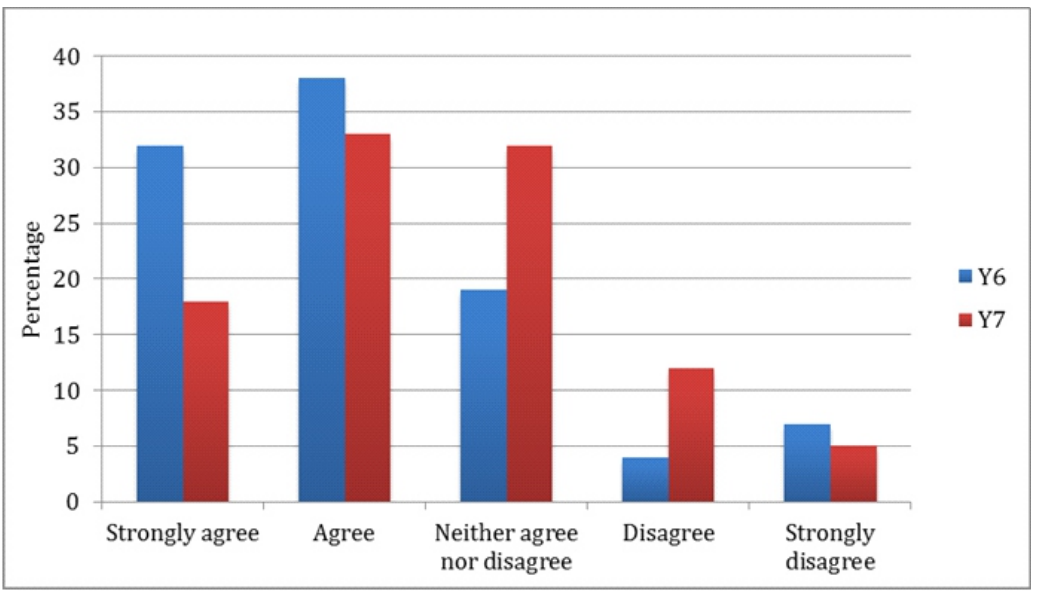

I think the best way I teach pupils in my class is by modelling myself. If I have been a bit snappy the pupils' behaviour changes immediately, especially those who have poor social skills. I will over model kindness and it has an enormous effect on the pupils, because I am their teacher and they almost subconsciously imitate and take their role from me. And if I am very kind, polite and very considerate ... it has an enormous effect on how the pupils react to that.

Documentary analysis suggests that in the primary schools there was a clear emphasis on the teaching of values and character development in the primary school. For example, in School 1 there was a strong emphasis on 'effective pastoral care and support and positive school atmosphere', which was borne out in their 2008 Ofsted inspection report. School 2 strongly focused on pupils' personal and social development, which was reflected in the school's twelve Golden Rules. In Schools 4 and 5, pupils were taught values partly through the PHSE programme (The Social and Emotional Aspects of Learning (SEAL) programme), the Golden Curriculum and also through the school's Golden Rules. In School 5 pupils were also taught good qualities and conduct through the use of 'circle time' methodology in class, the school council, a pupil 'buddying' system. Assemblies were often based on a story with a moral meaning, which was clarified for the pupils.

In the secondary schools, the focus was on personal responsibility, self-esteem, positive attitude and learning. This is summarised in the ethos of School 7 which states that the aim of the school was to develop 'happy, confident and hardworking pupils who display a responsible attitude to their development, have high aspirations and growing independence and possess good self esteem'. In all the secondary schools surveyed there was a notable emphasis on academic achievement. Teachers tended to view their role in pupils' values development within the context of the curriculum; that is the extent to which they provided appropriate and challenging work, the way they taught the lesson, or the extent to which they addressed team work or sharing in the ways in which pupils worked together.

The 2017 DfE report (DfE, 2017) found that the character development efforts in schools are focused on developing good citizenship (97\%) and academic attainment (84\%), and emphasis is placed on character traits such as honesty, integrity and respect for others (94\%).

Although schools emphasized character traits like honesty, integrity and respect for others, in practice pupils, particularly those in the secondary schools, found it difficult to trust and respect teachers.

Interviews with pupils suggest that primary school pupils found it easier to trust their teacher since they have mainly one teacher in comparison to secondary pupils who are likely to be taught by multiple teachers. Also, they tend to spend more time with that one teacher in the primary school than they do in the secondary school. They believed that having one teacher in primary school had helped them to build trust in that person - indicating that the time spent in the company of one teacher can be formative. For example, one secondary school pupil said:

\section{You don't really talk to teachers here. It's not so easy.}

Some commentators believe that this difference in attitude towards teachers is because secondary pupils are at an age when they are no longer restrained from expressing this kind of feeling by a childish reverence towards their teachers (Grisay, 1997; Dubet, 1999). 
Whatever the reason, the message is clear; secondary school pupils do not have an entirely positive view of their teachers. Only $65 \%$ of secondary school pupils reported that they trusted their teachers compared to $83 \%$ for primary school pupils. They were more likely to say that they trust the police more than their teachers (see Figure 3). Could it be that they see the police as a figure of authority and respect, but not their teachers? If schools and teachers are to play a role in the character development of young people, efforts have to be made to build that trust and respect. As La Taille (2006) explained, adults are important references in young people's construction of a moral sense, mistrust in adults such as teachers may hamper their moral development.

Figure 3. People pupils are more likely to trust

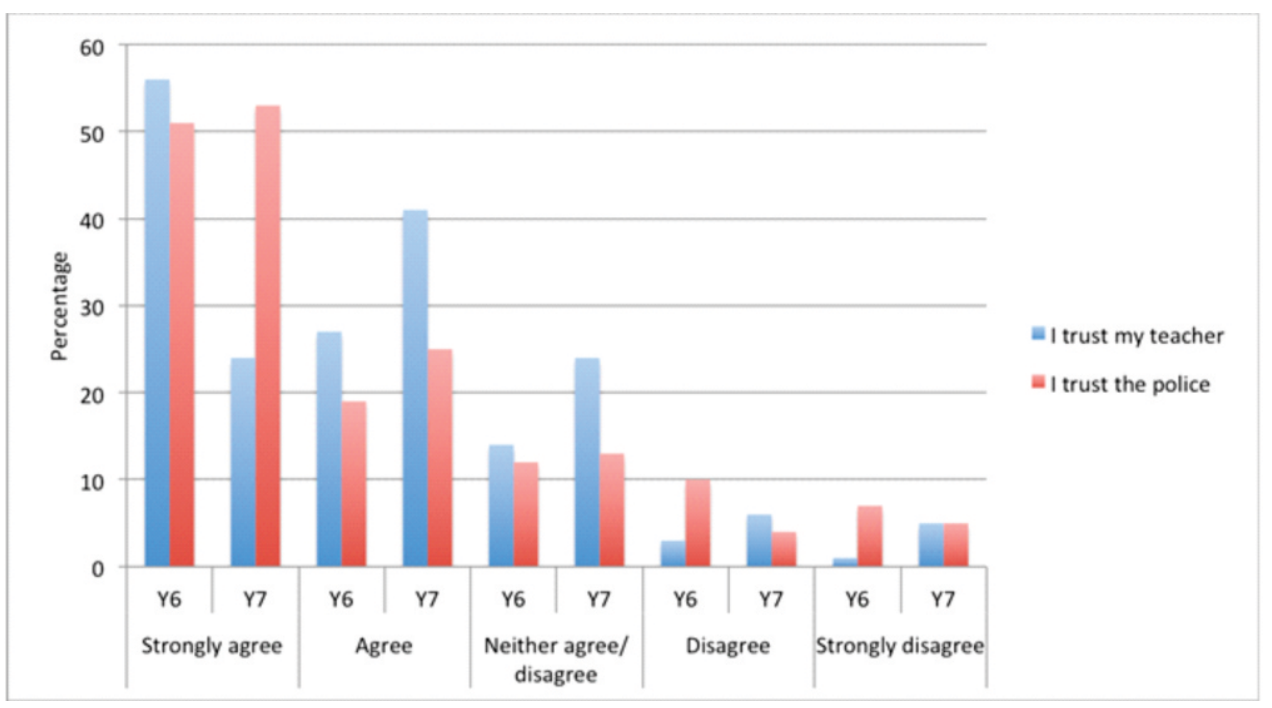

A number of secondary teachers in the interviews agreed that there was a need to develop good relationships based on trust and respect. This Is pivotal in character development for young people. According to Borba (2002), the early adolescent years are when pupils need most guidance in making tough moral choices. For those pupils where such guidance is lacking at home, the role of teachers as secondary carers becomes significant.

\section{Discussion}

There is generally little difference between primary and secondary school pupils' understanding of moral values. The majority or children valued trust and honesty but not courtesy and tolerance. This perhaps explains the general lack of respect and tolerance for authority among young people. In general, young people show a reasonable level of moral awareness and were able to identify with values generally associated with ethical behaviour. Most believed that they possessed some characteristics of a good person.

The findings also highlight the important influence of family, teachers and peer on character development. Although the influence of parents, especially mothers, on character formation is widely acknowledged, pupils' explained that it was the amount of time that these significant others spent with them and the examples they set that were important. This has important implications for recent government policy on educating parents as natural moral agents.

The biggest difference between pupils in $Y 6$ and $Y 7$ is their perception of the influence that teachers have on their character development. Primary school pupils were more likely than their secondary school counterparts to trust their teachers and recognise the positive influence their teachers have on their character development. Some possible explanations for this change could be the reduction in the amount of contact time pupils have with individual teachers in the secondary school, the shift in emphasis in the curriculum and the size of the school. For example, in the primary school, pupils had more contact with their form teachers. As a result, there was a closer pupil-teacher relationship. In secondary schools, pupils now interact with a wider range of teachers on a day to day basis. Moreover, being new to the school, pupils have less time to get to know their teachers and to build a rapport with them. In addition, there is also a shift from a more personal, pastoral approach in the primary school to a more instrumental, exam-oriented one in secondary school. Secondary schools tend to be larger in size, thus, fostering detachment. This move from a secure and familiar environment 
in the primary school to a new environment, with new teachers, new routines and expectations can make it difficult for the adolescents to trust their teachers. This is important as trust is one of two values rated highly by children.

These findings have important implications for schools and education in general and highlight the need for greater communication between primary and secondary schools to ensure continuity and to build trust and respect for teachers. Some suggestions on how this can be achieved include involving primary pupils in local secondary schools' activities. For example, joint activities such as games, sports (e.g. football matches), science fairs or language weeks could be organised which involve both primary and secondary school pupils.Secondary schools with 'feeder' primary schools could work in partnership whereby teachers in the first year of secondary school and those in the last year of primary school could be involved in joint activities.

There could also be greater continuity in the more personal approach to education often found in primary schools by re-emphasising the pastoral care ethos which is prevalent in the primary school and foster closer pupil-teacher relationships. Some studies have suggested that helping children develop a moral identity can enhance their social and academic success (Kohlberg 1976) and build trust and respect in teachers. There is evidence that better and more consistent pupil-teacher relations may have an impact on learning, behaviour and attendance (Sakiz \& Woolfolk-Kay, 2009; Gorard \& See, 2011). As some commentators have observed, pupils with the most serious problems in school are those with the poorest relationships with their teachers (Gorard, 2007; Boulton et al. 2009).

However, it is equally important that teachers demonstrate the kind of moral behaviour we want to see in our pupils (See \& Arthur, 2011). One way to do this is by role modelling. As Likona (1983, p.20) put it:

One of the surest ways to help our children turn their moral reasoning into positive moral behaviour is to teach by example. Teaching kids respect by respecting them is certainly one way to teach by example... But teaching by example, goes beyond how we treat children. It has to do with how we treat and talk about others...

It is not enough to have a curriculum for citizenship or moral education if pupils themselves do not experience this kind of behaviour in their interaction with their teachers (Gorard \& See, 2011). As Gorard (2007) says: 'Schools, in their structure and organisation, can do more than simply reflect the society we have; they can try to be the precursor of the kind of society that we wish to have.' As Berkowitz (1997) said: "Effective character education is not adding a program or set of programs to a school. Rather it is a transformation of the culture and life of the school."

Throughout history, education has been championed by character educators and moral philosophers as a solution to social problems (Damon, 2005). For example, Herbert Spencer said, 'education has for its object the formation of character' (Purpel and Ryan, 1976, cited in Huitt, 2004, p. 1). John Locke advocated education as education for character development (Huitt, 2004, p. 1) and Emile Durkheim argued that 'the task of the school in the moral development of the child can and should be of the greatest importance' (Durkheim, 1961, pp. 18-19). As Ryan (1993, p. 16) noted, while the development of a child's character is not the sole responsibility of the school, historically schools have been major players in this arena.

The key message from this study is that schools and teachers can play a part play in the character development of young people (De Vries, 1998; Wynne and Walberg, 1985). Anderson (2000, p. 139) believed that the classroom is where positive character traits could be reinforced, modelled and practised. Character education 'is a part of school life' and schools shape character (Doyle, 1997). This is especially so in homes where parents or family members are unable to provide the moral foundation for character development.

\section{Caveats}

We feel that it is important to mention some of the complex issues of data collection and sampling and explain how we have dealt with them to warrant the conclusions we have made.

First, the sample was taken from eleven schools (5 primary and 6 secondary), from one county in South-east England with a predominantly White pupil population. The schools and pupils were not randomly selected. Therefore, we would be tentative in generalising the findings to a wider population. 
Second, as we were not able to trace most of the students from Y 6 through to $\mathrm{Y} 7$ (only $9 \%$ of the pupils involved in the first survey took part in the second one), the study can only provide a differentiated snapshot of the experiences of pupils, rather than a truly longitudinal perspective. The discussion is therefore about differences between the two year groups, rather than about change over time, as we are not comparing the same group of students over time. The findings are nevertheless relevant in so far as they show differences in the views of Y6 and Y7 pupils.

Third, the data was primarily based on self-reporting and self-representation. It is possible that some pupils may be more reticent in highlighting their own "goodness", and some may be more honest in reporting than others.

Fourth, we acknowledge that there may be potentially important variables that were not measured and this might lead us to over-emphasise those we do have. However, this is not unusual as it is often not possible to tell in advance what the important variables might be.

Finally, we would like to add that these kinds of problems are to be expected in any real-life research project of this scale and should not compromise the findings.

\section{Acknowledgements}

The study was funded by the John Templeton Foundation. Thanks goes to James Arthur and the authors of the report, Consistency in Values (Arthur et al. 2010)

\section{ORCID ID}

Beng Huat See (D) http://orcid.org/0000-0001-7500-379X

\section{Appendix}

\section{Appendix A}

\section{Group Interview Schedule}

(Explain who you are, the purpose of the research, the purpose of interviewing them and that their responses are anonymous. Ask permission to record their responses)

\section{'Good' qualities}

Pupils work in pairs. Each is given a piece of paper and a pen. Through discussion, they decide on two people they think are good (this could be famous people, people within their family/ school or people they know). They discuss why they think they are good (the important thing is what they are saying as they discuss it). They write down the names of the people and feed back to the group.

Researcher explains that they have already been discussing why they think these people are good. Ask each to feed back one reason why they thought the person was good. Ask pupils to work in same pair again and to write three qualities these people have which make them good. Each child feeds back to the group. Researcher writes 'good' qualities on the board as they are listed and reads them back at the end.

Pupils work in pairs to consider:

1. What behaviour shows you that these people are e.g. honest (select one of the good qualities they have highlighted in their pairs)?

2. What kinds of actions show us that they are e.g. an honest person (select one of the good qualities they have highlighted in their pairs)?

3. What might these people be thinking if they are e.g. honest?

4. Looking at the list on the board- work in pairs to put them in order of importance, i.e. the one you consider to be most important comes first etc.

5. Discuss in pairs: Think of someone who is kind. Do you think they are kind all the time? Why/why not?

6. Imagine you had to get a lot of work done and one of your friends kept talking to you. How would you react? Kindly/unkindly? If you did react kindly towards them what made you do that? If you acted unkindly towards them what made you do that?

7. Discuss in pairs: Imagine your next door neighbour is a retired lady/man who lives alone. You know her/him well. She/he asks you to go to the local shop to get them some milk and starts to give you the money. Your friends are impatiently waiting for you to come and play with them. You really want to go and play with your friends. What would you do? Why? What made you act in that way? What sort of 
thoughts/feelings would you have?

8a. Are you a good person?

8b. How do you know? (What characteristics do you have that make you a good person?)

$8 \mathrm{c}$. Do you want to be a good person?

$8 d$. Do you like being a good person?

$8 \mathrm{e}$.What/who helps you to be a good person? How does it/he/she help you to be a good person? 
Appendix B: Questionnaire 1

\section{learningforlife \\ embracing core values}

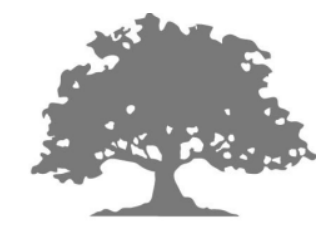

\section{Questionnaire}

This questionnaire will be anonymous. We will remove your name as soon as we have matched the questionnaire you do this year with the one you will do next year.

Name:
Sex: (Please circle)
Male
Female

School: 
My Religion: (Please circle one of the following)

Church of England (Anglican)

Catholicism (Roman Catholic)

Other Christian (Methodist, Baptist, United Reformist)

Islam (Muslim)

Judaism (Jew)

Hinduism (Hindu)

Sikhism (Sikh)

Other (please state)

None

What is your favourite school subject?

Do you like your school? (Please circle your response)

Yes

No

1 


\section{THE QUESTIONNAIRE}

\section{ANSWERING THE QUESTIONS}

Please put a circle around the response you choose. If you do not understand a question, do not answer it.

KEY:

$1=$ strongly agree

2=agree

$3=$ neither agree/disagree

4=disagree

$5=$ strongly disagree

\section{SECTION ONE: A Good Person}

1. A good person is kind, caring and loving $\begin{array}{llllll}1 & 2 & 3 & 4 & 5\end{array}$

2. A good person lets his/her moods $\quad \begin{array}{llllll}1 & 2 & 3 & 4 & 5\end{array}$ influence how he/she behaves

3. A good person thinks before he/she acts $\begin{array}{llllll}1 & 2 & 3 & 4 & 5\end{array}$

4. A good person is friendly, helpful and $\quad \begin{array}{llllll}1 & 2 & 3 & 4 & 5\end{array}$ welcoming to others

5. A good person has religious faith $\quad \begin{array}{lllll}1 & 2 & 3 & 4 & 5\end{array}$

6. A good person is trustworthy and loyal $\quad \begin{array}{lllll}1 & 2 & 3 & 4 & 5\end{array}$

7. A good person is someone with values $\quad \begin{array}{llllll}1 & 2 & 3 & 4 & 5\end{array}$

8. A good person never thinks badly of $\quad \begin{array}{llllll}1 & 2 & 3 & 4 & 5\end{array}$ him/her self

9. A good person never thinks badly of other $\begin{array}{llllll}1 & 2 & 3 & 4 & 5\end{array}$ people

10. A good person is cheerful and always $\quad \begin{array}{llllll}1 & 2 & 3 & 4 & 5\end{array}$ looks on the bright side

11. A good person knows that thinking good $\quad \begin{array}{llllll}1 & 2 & 3 & 4 & 5\end{array}$ thoughts is important 
12. A good person knows that doing good acts $\begin{array}{llllll}1 & 2 & 3 & 4 & 5\end{array}$ is important

13. A good person is someone with virtues $\quad \begin{array}{llllll}1 & 2 & 3 & 4 & 5\end{array}$

14. A good person is responsible $\quad \begin{array}{llllll} & 2 & 3 & 4 & 5\end{array}$

15. $A$ good person wants to be good in all $\quad \begin{array}{llllll}1 & 2 & 3 & 4 & 5\end{array}$ situations

16. A good person tries not to be unkind to $\quad \begin{array}{llllll}1 & 2 & 3 & 4 & 5\end{array}$ friends, even if they are annoying him/her.

17. A good person does not give up when $\quad \begin{array}{llllll}1 & 2 & 3 & 4 & 5\end{array}$ something is hard

18. It is important for a good person that $\quad \begin{array}{llllll}1 & 2 & 3 & 4 & 5\end{array}$ his/her friends think well of him/her

19. A good person attends a place of worship $\begin{array}{llllll}1 & 2 & 3 & 4 & 5\end{array}$

20. A good person does not always behave/act $\begin{array}{llllll}1 & 2 & 3 & 4 & 5\end{array}$ in the way he/she thinks or feels

21. A good person cares for the environment $\begin{array}{llllll}1 & 2 & 3 & 4 & 5\end{array}$

SECTION TWO: Thinking about Yourself

KEY:

$1=$ strongly agree

2=agree

$3=$ neither agree/disagree

4=disagree

$5=$ strongly disagree

22. I am kind, caring and loving $\quad \begin{array}{llllll}1 & 2 & 3 & 4 & 5\end{array}$

23. I let my moods influence how I behave $\quad \begin{array}{llllll}1 & 2 & 3 & 4 & 5\end{array}$

24. I think before I act $\quad 1 \quad \begin{array}{lllll}2 & 3 & 4 & 5\end{array}$ 
25. I am friendly, helpful and welcoming to $\begin{array}{llllll}1 & 2 & 3 & 4 & 5\end{array}$ others

26. I have a religious faith

$\begin{array}{lllll}1 & 2 & 3 & 4 & 5\end{array}$

27. I am trustworthy and loyal

$\begin{array}{lllll}1 & 2 & 3 & 4 & 5\end{array}$

28. I am a person with values

$\begin{array}{lllll}1 & 2 & 3 & 4 & 5\end{array}$

29. I never think badly of myself

$\begin{array}{lllll}1 & 2 & 3 & 4 & 5\end{array}$

30. I never think badly of other people

$\begin{array}{lllll}1 & 2 & 3 & 4 & 5\end{array}$

31. I am cheerful and always look on the

$\begin{array}{lllll}1 & 2 & 3 & 4 & 5\end{array}$ bright side

32. I know that thinking good thoughts is $\quad \begin{array}{llllll}1 & 2 & 3 & 4 & 5\end{array}$ important

33. I know that doing good acts is important $\begin{array}{llllll}1 & 2 & 3 & 4 & 5\end{array}$

$\begin{array}{lllllll}\text { 34. I am a virtuous person } & 1 & 2 & 3 & 4 & 5\end{array}$

35. I am responsible $\quad 1 \quad 2 \quad 3 \quad 3 \quad 4 \quad 5$

36. I want to be good in all situations $\quad \begin{array}{llllll} & 1 & 2 & 3 & 4 & 5\end{array}$

37. I try not to be unkind to friends, even if $\begin{array}{llllll}1 & 2 & 3 & 4 & 5\end{array}$ they are annoying me

38. I do not give up even when things are $\quad \begin{array}{llllll}1 & 2 & 3 & 4 & 5\end{array}$ hard

39. It is important for me that my friends $\quad \begin{array}{llllll}1 & 2 & 3 & 4 & 5\end{array}$ think well of me

40. I attend a place of worship

$\begin{array}{lllll}1 & 2 & 3 & 4 & 5\end{array}$

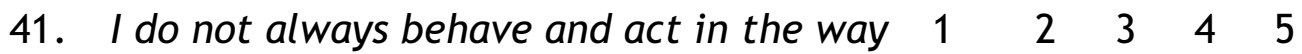
I think or feel

42. I care for the environment

$\begin{array}{lllll}1 & 2 & 3 & 4 & 5\end{array}$ 
SECTION THREE: Thinking about what helps you to be a Good Person

KEY:

$1=$ strongly agree

2=agree

$3=$ neither agree/disagree

$4=$ disagree

$5=$ strongly disagree

43. My teacher helps me to develop my $\quad \begin{array}{llllll}1 & 2 & 3 & 4 & 5\end{array}$ character

44. My school helps me to build my character $1 \begin{array}{lllll}1 & 2 & 3 & 4 & 5\end{array}$

45. I am only friends with people who are $\quad \begin{array}{llllll}1 & 2 & 3 & 4 & 5\end{array}$ good

46. The following help me to know how to be a good person:

$\begin{array}{llllll}\text { Mother/female carer/guardian } & 1 & 2 & 3 & 4 & 5\end{array}$

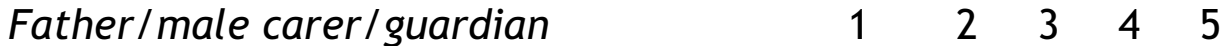

$\begin{array}{llllll}\text { Sisters/brothers } & 1 & 2 & 3 & 4 & 5\end{array}$

$\begin{array}{llllll}\text { Grandparents } & 1 & 2 & 3 & 4 & 5\end{array}$

Friends

Teachers

School

People on TV

Going to my place of worship

No one, I know how to be good myself

$\begin{array}{lllll}1 & 2 & 3 & 4 & 5\end{array}$

$\begin{array}{lllll}1 & 2 & 3 & 4 & 5\end{array}$

$\begin{array}{lllll}1 & 2 & 3 & 4 & 5\end{array}$

$\begin{array}{lllll}1 & 2 & 3 & 4 & 5\end{array}$

$\begin{array}{lllll}1 & 2 & 3 & 4 & 5\end{array}$

$\begin{array}{lllll}1 & 2 & 3 & 4 & 5\end{array}$

47. The following help me to act like a good person:

Mother/female carer/guardian

Father/male carer/guardian

Sisters/brothers

Grandparents

Friends

Teachers

School

People on TV

Going to my place of worship

No one, I know how to be good myself

$\begin{array}{lllll}1 & 2 & 3 & 4 & 5 \\ 1 & 2 & 3 & 4 & 5 \\ 1 & 2 & 3 & 4 & 5 \\ 1 & 2 & 3 & 4 & 5 \\ 1 & 2 & 3 & 4 & 5 \\ 1 & 2 & 3 & 4 & 5 \\ 1 & 2 & 3 & 4 & 5 \\ 1 & 2 & 3 & 4 & 5 \\ 1 & 2 & 3 & 4 & 5 \\ 1 & 2 & 3 & 4 & 5\end{array}$


48. A person cannot know if he/she is good. It $11 \quad \begin{array}{lllll}1 & 2 & 3 & 4 & 5\end{array}$ depends if other people think he/she is a good person

49. In one sentence, please tell me what 'virtue' means:

Thank you for completing this questionnaire 
Appendix C: Questionnaire 2

\section{learningforlife}

embracing core values

Questionnaire

CANTERBURY

Sex: (Please circle) Male Female

Secondary School:

Primary School:

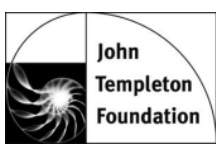

Canterbury
Christ Church
University 
My Religion: (Please circle one of the following)

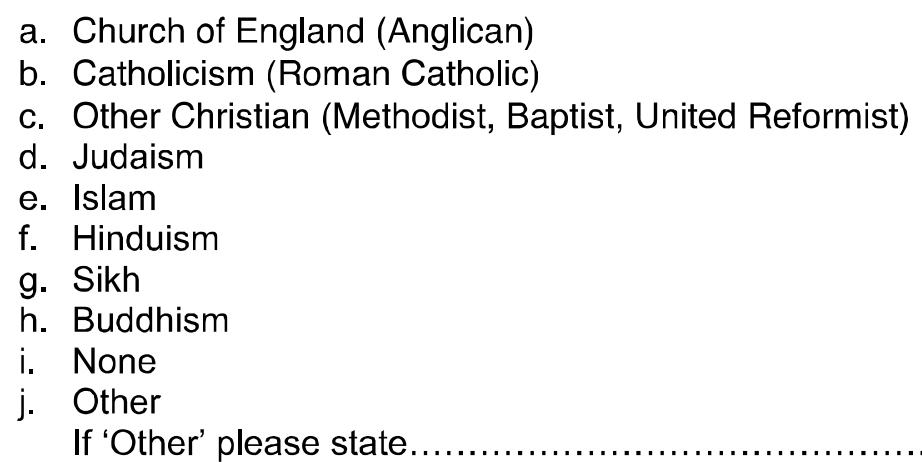

My Ethnic Group is: (Please circle one)
a. White
b. Pakistani
c. Indian
d. Caribbean
e. African
f. Eastern European
g. Chinese
h. Mixed
If Other please state

My Parent or Guardian attended: (Please circle one)
a. University
b. College
c. Went straight into work from school

In my family I have: (Please circle one)
a. 1 brother or sister
b. 2 brothers or sisters
c. 3 brothers or sisters
d. 4 brothers and sisters
e. Over 4 brothers and sisters
f. No brothers or sisters

Do you want to go to University? (Please circle one)
a. Yes
b. No

I see myself as (Please circle all that apply)
a. English yes/no
b. British yes/no
c. Both yes/no
d. European yes/no
e. Other (please state) 


\section{ANSWERING THE QUESTIONS}

Please put a circle around the response you choose. If you do not understand a question, ask the teacher to explain.

KEY:

$1=$ strongly agree

2=agree

$3=$ neither agree/disagree

$4=$ disagree

$5=$ strongly disagree

\section{SECTION ONE: Character and Values}

1. I am proud of Canterbury

2. I trust my teachers

3. I trust my neighbours

4. I trust the police

5. There's not really that much to look forward to

6. I have pride in Britain

7. I value my friends very much

8. Good manners are important $\begin{array}{lllll}1 & 2 & 3 & 4 & 5\end{array}$

9. To have character is to have a set of qualities that 1 make you into a rounded person

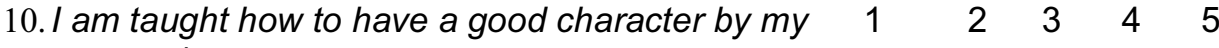
parents/carers

11. I am taught how to have a good character by my $\quad \begin{array}{llllll}1 & 2 & 3 & 4 & 5\end{array}$ teachers

\section{SECTION TWO: Religion and Family}

12. Religion is important

13. Religion helps people be better people

14. I am proud of my family background

15. Religion helps me to be a better person

16. Religion is very important in my life 
KEY:

$1=$ strongly agree

2=agree

$3=$ neither agree/disagree

$4=$ disagree

$5=$ strongly disagree

\section{SECTION THREE: Education}

17. School could do more to build my character $\quad \begin{array}{llllll}1 & 2 & 3 & 4 & 5\end{array}$

18. I speak up when I see someone being bullied $\quad \begin{array}{llllll}1 & 2 & 3 & 4 & 5\end{array}$

19. I cheat sometimes on a test or in homework $\quad \begin{array}{llllll}1 & 2 & 3 & 4 & 5\end{array}$

20. I admit when I make a mistake $\quad \begin{array}{lllll}1 & 2 & 3 & 4 & 5\end{array}$

21. Teachers ask me my opinion in school $\quad \begin{array}{llllll}1 & 2 & 3 & 4 & 5\end{array}$

22. Teachers listen carefully to my explanation of $\quad \begin{array}{llllll}1 & 2 & 3 & 4 & 5\end{array}$ why I disagree with them

23. Education is very important for my future $\quad \begin{array}{llllll}1 & 2 & 3 & 4 & 5\end{array}$

24. Teachers explain the reasons for a rule or $\quad \begin{array}{llllll}1 & 2 & 3 & 4 & 5\end{array}$ punishment

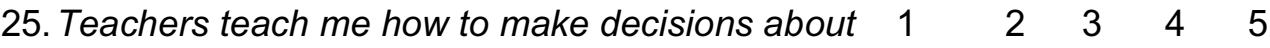
moral issues or problems in life

26. Pupils here are willing to share with others, even $\quad \begin{array}{llllll}1 & 2 & 3 & 4 & 5\end{array}$ if they are not friends

27. Pupils here resolve conflict without fighting or $\quad \begin{array}{llllll}1 & 2 & 3 & 4 & 5\end{array}$ threats

28. Pupils here do not care if their friends cheat $\quad \begin{array}{lllllll}1 & 2 & 3 & 4 & 5\end{array}$

29. Pupils should not spread rumours or gossip $\quad \begin{array}{llllll}1 & 2 & 3 & 4 & 5\end{array}$ 


\section{SECTION FOUR: Being a Citizen}

$\begin{array}{lllllll}30 . I \text { have a responsibility to care for the environment } & 1 & 2 & 3 & 4 & 5\end{array}$

$\begin{array}{lllllll}\text { 31. Caring for the environment is not my } & 1 & 2 & 3 & 4 & 5\end{array}$ responsibility

32. Being British doesn't actually mean anything to $\begin{array}{lllllll}1 & 2 & 3 & 4 & 5\end{array}$ me

33. I understand the British way of life

34. I sometimes give to charity

35. Britain is a moral country

36. The police should do more in my community $\quad \begin{array}{llllll}1 & 2 & 3 & 4 & 5\end{array}$

37. Parents should develop their children's character $1 \begin{array}{llllll}1 & 2 & 3 & 4 & 5\end{array}$ more

38.I think you should try to get what you want out of $\begin{array}{llllll}1 & 2 & 3 & 4 & 5\end{array}$ life even if it means not helping other people

\section{SECTION FIVE: Community}

39. I volunteer and help in my local community

$\begin{array}{lllll}1 & 2 & 3 & 4 & 5\end{array}$

40.I volunteer and help in my school community

$\begin{array}{lllll}1 & 2 & 3 & 4 & 5\end{array}$

\section{SECTION SIX: The Media}

41. TV influences my behaviour

42. Playing games (on my own) on the internet influences my behaviour

43. The TV influences my character more than the internet

44. Please indicate whether you think the following are important to you:
a. Tolerance
b. Justice
c. Loyalty
d. Trust
e. Honesty
f. Courtesy

$\begin{array}{lllll}1 & 2 & 3 & 4 & 5\end{array}$

$\begin{array}{lllll}1 & 2 & 3 & 4 & 5\end{array}$

$\begin{array}{lllll}1 & 2 & 3 & 4 & 5\end{array}$ 


\section{Answer the following ONLY if you are in year 6}

45. I am happy in year 6

46. I enjoy school life

47. I have lots of friends in my class

48. I like being one of the oldest/biggest children in the school

49. I am expected to take responsibility for organising myself in class

50. I enjoy school work

51. I enjoy doing well in class

52. School is boring

53. My teacher cares about me as a person

54. My teacher gives me all the help I need with my work

55. My teacher helps me to develop positive attitudes

56. My teacher helps me to develop good behaviour

57. My teacher helps me to build my character

58. My friends influence how I act/behave

59. I am looking forward to going to secondary school

60. I think I will enjoy the work in secondary school

61. I am looking forward to making lots of new friends

62. I am worried about going to secondary school

63. I am worried that I might be bullied in secondary school

64. My teacher in year 6 is preparing me well for moving to secondary school

$\begin{array}{lllll}1 & 2 & 3 & 4 & 5 \\ 1 & 2 & 3 & 4 & 5 \\ 1 & 2 & 3 & 4 & 5 \\ 1 & 2 & 3 & 4 & 5\end{array}$

$\begin{array}{lllll}1 & 2 & 3 & 4 & 5\end{array}$

$\begin{array}{lllll}1 & 2 & 3 & 4 & 5\end{array}$

$\begin{array}{lllll}1 & 2 & 3 & 4 & 5\end{array}$

$\begin{array}{lllll}1 & 2 & 3 & 4 & 5\end{array}$

$\begin{array}{lllll}1 & 2 & 3 & 4 & 5\end{array}$

$\begin{array}{lllll}1 & 2 & 3 & 4 & 5\end{array}$

$\begin{array}{lllll}1 & 2 & 3 & 4 & 5\end{array}$

$\begin{array}{lllll}1 & 2 & 3 & 4 & 5\end{array}$

$\begin{array}{lllll}1 & 2 & 3 & 4 & 5\end{array}$

$\begin{array}{lllll}1 & 2 & 3 & 4 & 5\end{array}$

$\begin{array}{lllll}1 & 2 & 3 & 4 & 5\end{array}$

$\begin{array}{lllll}1 & 2 & 3 & 4 & 5\end{array}$

$\begin{array}{lllll}1 & 2 & 3 & 4 & 5\end{array}$

$\begin{array}{lllll}1 & 2 & 3 & 4 & 5\end{array}$

$\begin{array}{lllll}1 & 2 & 3 & 4 & 5\end{array}$

$\begin{array}{lllll}1 & 2 & 3 & 4 & 5\end{array}$ 


\section{Answer the following ONLY if you are in year 7}

65. My teacher in year 6 prepared me well for moving to secondary school

66. I am happier in year 7 than I was in year 6

67. I enjoy school life

68. I have lots of friends in my class

69. I do not like being one of the youngest/smallest children in the school

70. I am expected to take responsibility for organising myself in class

71. I enjoy doing well in class

72. School is boring

73. I like having different teachers for different lessons

74. My teachers care about me as a person

75. My teachers give me all the help I need with my work

76. My teachers help me to develop positive attitudes

77. My teachers help me to develop good behaviour

78. My friends influence how I act/behave

79. My teachers in year 7 do more to help me build my character than my teacher in year 6

80. My teachers treat me in a more grown up way in $\begin{array}{llllll}1 & 2 & 3 & 4 & 5\end{array}$ year 7

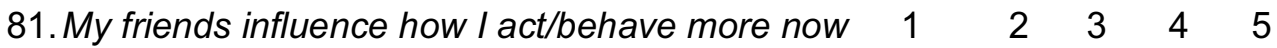
than when I was in year 6

82. There is more bullying in secondary school than $\begin{array}{llllll}1 & 2 & 3 & 4 & 5\end{array}$ in primary school

83. I liked primary school more than I like secondary $\begin{array}{lllllll}1 & 2 & 3 & 4 & 5\end{array}$ school 


\section{References}

Arthur, J., Davison, J., See, BH.,\& Knowles, C. (2010). Consistency in values: the transition from primary to secondary school. Character in transition. Birmingham: University of Birmingham.

Anderson, D.R. (2000). Character education: Who is responsible? Journal of Instructional Psychology, 27(3), 139-141.

Battistich, V., Schaps, E., \& Wilson, N. (2004). Effects of an elementary school intervention on students' "connectedness" to school and social adjustment during middle school. Journal of Primary Prevention, 24, 243-262.

Battistich, V., \& Hom, A. (1997). The relationships between students' sense of their school as a community and their involvement in problem behaviors. American Journal of Public Health, 87, 1997-2001.

Berkowitz, M.W. (1997). The complete moral person: Anatomy and formation. In J.M.DuBois (Ed.), Moral issues in psychology: Personalist contributions to selected problems (pp. 11-42). Lanham, MD: University Press of America.

Berkowitz, M.W., \&Bier, M.C. (2005). What works in character education: A research-driven guide for educators. Washington, DC: Character Education Partnership. Retrieved from: http://www,character. org/files/practitioners_518.pdf

Berkowitz, M.W. (2012). Obstacles to teacher training in character education. Action in Teacher Education, 20(4), 1-10.

Berkowitz, M.W., and Bier, M.C. (2004). Research-based character education. The Annals of the American Academy of Political and Social Science, 591(1), 72-85.

Berkowitz, M.W., \&Grych, J.H. (1998). Journal of Moral Education, 27(3), 371-391.

Borba, M. (2002).Building moral intelligence: the seven essential virtues that teach kids to do the right thing. San Francisco: Jossey Bass.

Boulton, M., Duke. E., Holma, G., Laxton, E., Nicholas, B, Spells, R., .., Woodmansey, H. (2009). Associations between being bullied, perceptions of safety in classroom and playground, and relationship with teacher among primary school pupils, Educational Studies, 35(3),255-267

Cabinet Office (2011). PM's speech on the fightback after the riots. London: HMSO. Retrieved from: https://www.gov.uk/government/speeches/pms-speech-on-the-fightback-after-the-riots

Campbell, E. (2003). The ethical teacher. New York: Open University Press.

Campbell, V. and Bond, R. (1982) Evaluation of a character education curriculum. In McClelland, D. (ed.) Education for values. New York: Irvington Publishers.

Cohen, T.R., \& Morse, L. (2014) Moral character: What it is and what it does. Research in Organisational Behaviour, 34, 43-61.

Colby, A., \&Kohberg, L. (1987). The measurement of moral judgment, Volume 1. New York: Cambridge University Press.

Damon, W. (2005). Good? Bad? Or none of the above? The unavoidable mandate to teach character. Education Next, 5(2), 20-27.

Davies, I., Gorard, S.,\& McGuinn, N. (2005). Citizenship studies and character studies: similarities and contrasts, British Journal of Educational Studies, 53(3),341-358.

De Vries, R. (1998). Implications of Piaget's constructivist theory for character education. Action in TeacherEducation, 20(4), 39-47.

DfEE (Department for Education and Employment). (1997). Excellence in schools. London: The Stationery Office.

DfEE (2001). The Green Paper, Schools: Building on success. London: The Stationery Office.

DfE (Department for Education)(2017) Developing character skills in schools. Report by NatCen Social Research and the National Children's Bureau Research and Policy Team. London: DfE.

DfES (Department for Education and Skills) (2001). The White Paper, Schools: Achieving Success.

Dietsch, B., Bayha, J.L., \& Zheng, H. (2005). Short-term effects of a character education program among fourth grade students. Paper presented at the American Educational Research Association 
annual meeting, Montreal, Quebec, Canada.

Doyle, D.P. (1997). Education and character: Aconservative view. Phi Delta Kappan, 78(6), 440-443.

Dubet, F. (1999). Sentiments et jugements de justice dans l'expérience scolaire, in Meuret, D. (ed.) La justice du système éducatif, Paris: de Boeck.

Durkheim, E. (1961). Moral education: A study in the theory and application of the sociology of education (E.K. Wilson and H. Schnurer, Trans.). New York: TheFree Press.

DIES (Department for Education and Skills) (2001). School archiving success, Annesley: DfES Publications.

Evangelou, M., Taggart, B., Sylva, K., Melhuish, E., Sammons, P., \&Siraj-Blatchford, I. (2008).What makes a successful transition from primary to secondary school? Findings from the Effective PreSchool, Primary and Secondary Education 3-14 (EPPSE) Project, Research Brief, January, DCSF.

Eyers, V., Cormack, P., \& Robyn, B. (1992) Report of the junior secondary review: the education of young adolescents in South Australian government schools, Adelaide, Education Department of S.A.

Flay, B.R., Acock, A., Vuchininch, S., Lewis, K., Bavarian, N., Schure, M.B.,...,Ji, P. (2012). Social emotional and character development to improve student behaviour and academic achievement: Results from two school-based randomized trials. Researchgate, Retrieved from: https://www. researchgate. net/publication/266505843_Social-Emotional_and_Character_Development_to_ Improve_Student_Behaviour_and_Academic_Achievement_Results_From_Two_School-Based_Randomized Trials

George, M.I. (2017) What moral character is and is not. The Linacre Quarterly, 84(3), 261-274.

Gorard, S. (2007). Justice et equite a l'ecole: ce qu'en dissent les eleves dans les etudes internationales, Revue Internationale d'Education Sevres, 44, April, 79-84.

Gorard, S.,\& See, BH. (2011). How can we enhance enjoyment of secondary school?: the student view. British Educational Research Journal, 37(4), 671-690.

Gorman-Smith, D., Tolan, P.H., Zelli, A., \&Huesmann, L.R. (1996). The relation of family functioning to violence among inner-city minority youths. Journal of Family Psychology, 10(2), 115-129. DOI: $10.1037 / / 0893-3200.10 .2 .115$

Graham, C.,\&Hill, M. (2003). Negotiating the transition to secondary school, SCRE Spotlight,89, September, 2-6.

Grassi, M., Nucera, A., Zanolin, E., Omennaas, E., Anto., J.,\& Leynaert, B. (2007) Performance comparison of likert and binary formats of SF-36 version 1.6 across ECRHS II adult populations. Value in Health, 10(6), 478-488.

Grisay, A. (1997). Evolution des acquis cognitifs et socio-affectifs des élèves au cours des années de collège, MEN-Direction de l'Evaluation et de la Prospective, Dossiers Education et formations.

Guerra, N.G., Huesmann, R.L., Tolan, P.T. Van Acker, R.,\& Eron, L.D. (1995). Stressful events and individual beliefs as correlates of economic disadvantage and aggression among urban children. Journal of Consulting and Clinical Psychology, 63(4), 518-528.

Hansen, D.T. (1993). From role to person: The moral layeredness of classroom teaching. American Educational Research Journal, 30(4), 651-674.

Hargreaves, A., Earl, L., \& Ryan, J. (1996) Schooling for change : reinventing education for early adolescents, London: The Falmer Press.

Harter, S. (1985).Manual for the self-perception profile for children. University of Denver: Denver CO.

Havighurst, R.J.,\&Taba, H. (1949) Adolescent character and personality. New York: Wiley.

Hawkins, D.J., Herrenkohl, T.I., Farrington, D.P., Brewer, D., Catalano, R.F., Harachi, T.W.\& Cothern, L. (2000) Predictors of youth violence. Juvenile Justice Bulletin, April 2000. Washington: Office of Juvenile Justice and Delinquency Prevention.

Helena Amstalden Imanishi; Vanessa Lopes dos Santos Passarelli; Yves Joel Jean-Marie Rodolphe de La Taille (2011) Morals in the adult world: how youth see their contemporary elders. Educational Pesqui,37(4).

Holstein, C.B. (1976). Development of moral judgment: A longitudinal study of males and females. Child Development, 47, 51-61. 
Huffington Post UK (2012).Young people and morality: Family love put first before religion. Huffngton Post UK. Retrieved from: https://www.huffingtonpost.co.uk/2012/09/12/young-people-social-moralityreligion-ethics-_n_1877016.html

Huitt, W. (2004).Moral and character development. Educational Psychology Interactive, Valdosta, GA: Valdosta State University. Retrieved from http://www.edpsycinteractive.org/morchr/morchr.html

Knodel, J. Havanon, N.,\& Pramualratana, A. (1984) Fertility transition in Thailand: A qualitative analysis. In Morgan, D. L. (ed.) (1993) Successful focus groups: advancing the state of the art. London: SAGE Publications.

Kohlberg, L. (1976). Moral stages and moralization: The cognitive-developmental approach. In T. Lickona (Ed.), Moral development and behavior: Theory, research, and social issues (pp.31-53). New York: Holt, Rinehart and Winston.

La Taille, (2006). The importance of generosity at the beginning of the genesis of morality in children. Psicologia: Reflexão e Crítica, 19(1), 9-17.

Layard, R, (2005).Happiness: Lessons from a new science, London: Allen Lane.

Layard, R., \& Dunn, J. (2009). A good childhood: searching for values in a competitive age, London: Penguin.

Lexmond, J.,\& Reeves, R. (2009) Building character. London: DEMOS

Lickona, T. (1983). Raising good children. New York: Bantam Books.

Matera, S. (2001). A cry for character. Paramus, NJ: Prentice Hall Press.

Measor, L.,\& Woods, P. (1984) Changing schools: pupil perspectives on transfer to a comprehensive school, Milton Keynes: Open University Press.

Mitchell, L. (2015) Integrity and Virtue: The forming of good character. The Linacre Quaterly, 82(2), 149-169.

Morgan, D.L. (1988) Focus groups as qualitative research. Newbury Park, CA: Sage.

Narvaez, D., \& Lapsley, D.K. (2008). Teaching moral character: Two alternatives for teacher education. TeacherEducator, 43(2), 156-172.

Purpel, D., \& Ryan, K. (Eds.). (1976). Moral education: It comes with the territory. Berkeley, CA: McCutchan.

Revell, L.,\& Arthur, J. (2007). Character education in schools and the education of teachers. Journal of Moral Education, 36(1), 79-92.

Rienzo, C., Rolfe, H.,\& Wilkinson, D. (2015).Changing Mindsets: Evaluation and executive summary. London: EEF

Ryan, K. (1993). Mining the Values in the Curriculum, Educational Leadership, 51(3),16-18.

Sakiz, G., \&Woolfolk-Hoy, A. (2009).Improving middle school students'academic enjoyment, academic self-efficacy, and academic effort in mathematics, EERA Annual conference, Prague. Retrieved from:http://www.eera-ecer.eu/ecer-programmes-and presentations/conference/ecer-2009/ contribution /q62-1/

Schwartz, D., \& Proctor, L.J. (2000). Community violence exposure and children's social adjustment in the school peer group: The mediating roles of emotion regulation and social cognition. Journal of Consulting and Clinical Psychology, 68(4), 670-683.

See, B.H.,\& Arthur, J. (2011). The potential role of schools and teachers in character development of young people in England: perspectives from pupils and teachers. Evaluation and Research in Education, 24(2), 143-157.

See, B.H., Gorard, S., \& Siddiqui, N. (2017) Does participation in uniformed group activities in school improve young people's non-cognitive outcomes? International Journal of Educational Research, 85 , $109-120$

Speicher, B. (1994). Family patterns of moral judgment during adolescence and early adulthood. Developmental Psychology, 30, 624-632.

Thompson, B. (2004). Transition to secondary school, Primary Practice, 38, $28-30$.

Tobbell, J. (2003). Students' experiences of the transition from primary to secondary school, Educational and Child Psychology, 20(4), 4-14. 
Walker, L.J., and Taylor, J.H. (1991). Family interactions and the development of moral reasoning. Child Development, 62, 264-283.

Webster-Stratton, C., Reid, M. J. and Stoolmiller, M. (2008). Preventing conduct problems and improving school readiness: Evaluation of the Incredible Years Teacher and Child Training Programs in high-risk schools. Journal of Child Psychology and Psychiatry, 49(5), 471-488.

Weller, S. (2007). 'Sticking with your mates' pupils' friendship trajectories during the transition from primary to secondary School, Pupils and Society, 21, 339-351.

Wynne, E., and Walberg, H. (1985). The complementary goals of character development and academic excellence. Educational Leadership, 43(4), 15-18.

Zeedyk, M.S., and Gallacher, J., (2003) Negotiating the Transition from Primary to Secondary School, School Psychology International, 24(1), 67-79. 